\title{
Axon-Regenerating Retinal Ganglion Cells in Adult Rats Synthesize the Cell Adhesion Molecule L1 but Not TAG-1 or SC-1
}

\author{
Marion Jung, ${ }^{1}$ Barbara Petrausch, ${ }^{1}$ and Claudia A. O. Stuermer \\ Faculty of Biology, University of Konstanz, D-78434 Konstanz, Germany
}

\begin{abstract}
Retinal ganglion cells (RGCs) in rats regenerate axons in the presence of a PNS nerve graft. To determine if axonregenerating RGCs synthesize cell adhesion/recognition molecules which they possessed during development, retinae were subjected to in situ hybridization with antisense cRNA probes of L1, TAG-1, and SC-1 (and GAP-43 for comparison). L1 and TAG-1 (and GAP-43) proteins on axons were detected with antibodies. L1, TAG-1, and SC-1 (and Gap-43) mRNAs and L1 and TAG-1 (and Gap-43) proteins were expressed by RGCs in embryonic, postnatal, and adult rats. After optic nerve lesion (ONL), the surviving RGCs between 2 and 28 days after ONL continue to express L1. TAG-1 and SC-1 expression, however, is lost. In grafted rats, axon-regenerating RGCs express L1 (together with GAP-43) but neither TAG-1 nor SC-1. Thus, axonal regeneration in grafted rats occurs in the presence of L1 (and GAP-43) but in the absence of TAG-1 and SC-1.
\end{abstract}

\section{INTRODUCTION}

Whether axotomized neurons in the vertebrate central nervous system (CNS) regenerate their axons critically depends on both the glial cell environment (reviewed in Schwab et al., 1993) and the neuron intrinsic conditions (Fawcett, 1992; Stuermer et al., 1992). Where glial cells are growth inhibiting, as in the mammalian CNS (Schwab et al., 1993), axonal regeneration fails to occur. Where they possess growth-promoting properties, as in the fish visual system (Bastmeyer et al., 1993; Wanner et al., 1995; Schwalb et al., 1996) and in the mammalian peripheral nervous system (PNS), severed axons regrow and restore lost functions (Gaze, 1970; Fawcett and Keynes, 1990).

A dramatic upregulation of $\mathrm{mRNA}$ and protein synthesis by all axotomized retinal ganglion cells (RGCs)

\footnotetext{
${ }^{1}$ The first two authors contributed equally to this study.
}

accompanies retinal axon regeneration in fish (Grafstein, 1986; Grafstein and McQuarrie, 1978), reflecting the neurons' intrinsic ability to reactivate the cellular mechanisms required for axon growth (Stuermer et al., 1992). Among the many proteins that underlie a lesioninduced upregulation in fish are GAP-43 (Benowitz and Lewis, 1983) and cell adhesion/recognition molecules of the immunoglobulin superfamily (IgSF CAMs), which are associated with axon growth in developing RGCs (Bastmeyer et al., 1990; Vielmetter et al., 1991; Paschke et al., 1992; Laessing et al., 1994; Laessing and Stuermer, 1996; Bernhard et al., 1996; Giordano et al., 1997). Functional analyses of these growth-related CAMs in fish, birds, and mammals demonstrate that they affect axon growth, fasciculation, and axonal pathfinding (reviewed in Brümmendorf and Rathjen, 1994, 1996). Moreover, they are suggested to contribute to axon and terminal arbor stabilization and target contact formation (Bartsch et al., 1989; Pollerberg et al., 1985; Paschke et al., 1992; Yamagata et al., 1995).

Unlike those of fish, axotomized RGCs in mammals fail to spontaneously regenerate their axons. Many are lost through cell death (Aguayo et al., 1991), but a proportion of those that survive produce GAP-43 (Skene, 1989; Doster et al., 1991), and roughly $4-5 \%$ are capable of regenerating long axons when a nerve of the PNS is grafted to the optic nerve stump (David and Aguayo, 1985; Aguayo et al., 1991).

One might expect that-as in fish-IgSF CAMs which were synthesized during axon development are present during RGC regeneration in mammals. Immunohistochemical studies showed the presence of the IgSF CAM L1 on growing and adult RGC axons in mice and rats (Bartsch et al., 1989; Mohajeri et al., 1996; Stallcup et al., 1985) and on rat axons in PNS grafts, although the latter were not unequivocally identified as RGC axons (Dezawa and Nagano, 1996). 
In this context, we asked (i) whether rat RGCs dynamically regulate the production of specific IgSF CAMs (in comparison to Gap-43): NILE, the homologue of L1 in rats (Prince et al., 1991; Bock et al., 1985) and henceforth called L1; SC-1 (SC-1/DM-GRASP; Tanaka et al., 1991; Burns et al., 1991); and TAG-1 (TAG-1/ axonin-1; Furley et al., 1990; Ruegg et al., 1989); (ii) whether RGCs exhibit a lesion-induced change in IgSF CAM production; and (iii) most importantly, whether RGCs synthesize CAMs during graft-assisted RGC axon regeneration.

\section{RESULTS}

To be able to judge whether axotomized and axonregenerating rat RGCs synthesize the CAMs L1, SC-1, and TAG-1 in correlation with axon growth and regeneration, we first needed to determine if and when these proteins are present in embryonic, postnatal, and adult rats. Changes following axotomy and the situation in rats having received a sciatic nerve graft (grafted rats) were evaluated subsequently. The presence of CAM expression was compared to that of GAP-43 at relevant stages because neurons upregulate GAP-43 during axon regeneration (Skene, 1989).

\section{Synthesis of L1, SC-1, and TAG-1 by RGCs in Embryonic, Postnatal, and Adult Rats}

In situ hybridizations with antisense cRNA probes of L1 and TAG-1 in E16 rat embryos resulted in intense cellular staining in the RGC layer, indicating that RGCs produce L1 and TAG-1 mRNAs during RGC axon growth (Figs. 1a and 1g). Consistent with earlier results (Kapfhammer et al., 1994; Reh et al., 1993), E16 RGCs also produced GAP-43 mRNA, as was revealed by in situ hybridization with the antisense GAP-43 cRNA probe. Experiments with an antisense cRNA probe of rat SC-1 gave no in situ hybridization signal in embryonic rat RGCs at stages E14 to E19. Signal, however, was intense in RGCs at postnatal stages P0-P15 (Figs. 1d and 1e).

In E16 embryos, antibodies against L1 and TAG-1 resulted in labeling of the developing RGC axons in the eye and optic nerve (Figs. $2 \mathrm{a}$ and $2 \mathrm{~b}$ ). These axons are also labeled by anti-GAP-43 (Reh et al., 1993). Antibody F84.1 against a PC-12 (pheochromocytoma) cell-derived SC-1-related protein (Prince et al., 1992) did not label RGC axons either in embryos or in adults, and polyclonal antisera against homologous proteins of other species were discarded because of the appearance of additional bands in Western blots. Further analysis of
SC-1 had thus to be performed by in situ hybridizations alone.

RGCs in postnatal (P0-P15) rats exhibited intense in situ hybridization signals with antisense cRNA probes of L1, SC-1, TAG-1, and GAP-43 (Figs. 1b, 1e, and 1h). In the case of TAG-1 and SC-1 staining intensity varied, especially with SC-1. Staining produced by in situ hybridization with antisense cRNA of L1 was intense in many more RGCs.

The presence of mRNAs correlated with anti-L1 and anti-TAG-1 (and anti GAP-43) immunoreactivities on RGC axons along their path through the retina and into the optic nerve (Fig. 2).

Adult rats continued to exhibit L1, SC-1, and TAG-1 mRNAs (Figs. 1c, 1f, and 1i). The density of cells carrying the in situ hybridization signals was markedly reduced compared to retinae at postnatal stages. This is consistent with the known progressive reduction in number of RGCs due to cell death (Clarke, 1985). As judged from the staining intensity resulting from the in situ hybridization procedure, the level of mRNA synthesis of SC-1 and TAG-1 was reduced (Figs. 1f and 1i) in most RGCs, but some were still deeply colored. The number of intensively stained cells was higher in the case of L1 mRNA detection, and it appears as if most or all RGCs carry the signal. GAP-43 mRNA was not detectable in adult RGCs, which is consistent with earlier results (Kapfhammer et al., 1994; Reh et al., 1993).

RGC axons in adult rats continued to be anti-L1 and anti-TAG-1 immunopositive. Anti-L1 staining ceased at the region in the optic nerve (Figs. $2 a^{\prime}$ and $2 b^{\prime}$ ) where axons are myelinated. A similar pattern has been reported in mouse (Bartsch et al., 1989). Anti-GAP-43 yielded no staining, as expected (Kapfhammer et al., 1994; Reh et al., 1993).

Thus, L1 and TAG-1 mRNAs were present at high concentrations in rat RGCs in embryonic and postnatal stages and RGC axons carried the protein on their surface. SC-1 mRNA was detectable in postnatal but not in embryonic RGCs. In adult rats [which downregulate GAP-43 (Skene, 1989)] RGCs continue to exhibit L1, SC-1, and TAG-1 mRNAs, and carry L1 (Bartsch et al., 1989) and TAG-1 proteins on the axonal surface.

\section{L1, SC-1, and TAG-1 after Optic Nerve Lesion}

To analyze whether rat RGCs regulate synthesis of L1, SC-1, and TAG-1 in response to optic nerve lesion (ONL), in situ hybridization experiments were performed with retinae between 2 to 28 days after ONL (Fig. 3). To obtain an estimate of the number of L1 mRNA-producing RGCs (for subsequent evaluation of 
mRNA-synthesizing RGCs in grafted rats), labeled RGCs were counted in $101-\mathrm{mm}^{2}$ quadrants of eight pieshaped segments per retina (at least four retinae per mRNA) and averaged. Average numbers per $\mathrm{mm}^{2}$ are presented in the histogram in Fig. 4. The topographic inhomogeneity of RGC numbers [with the temporal retina possessing roughly four times as many RGCs as the nasal retina (Villegas-Pérez et al., 1992; Bähr et al., 1992)] was disregarded because our study focuses on mRNA-producing RGCs in grafted rats (see below), which occur in low numbers throughout the retina. Compared to RGC counts in the literature (VillegasPérez et al., 1988, 1992; Bähr et al., 1992) it appears that most or perhaps all RGCs in the normal adult retina produce L1 mRNA. It was impossible to count RGCs producing TAG-1 and SC-1 mRNAs because of the weakness of stain in many or most RGCs. This did not negatively affect the later quantitative evaluation because these mRNAs are not present in RGCs of grafted rats (see below). The number of RGCs exhibiting L1 mRNA was compared to RGCs producing GAP-43 mRNA (Figs. 3 and 4). The number of RGCs containing in situ hybridization signals with the antisense L1 probe 2 days after ONL was statistically similar to the number in the normal retina. In parallel with the lesion-induced loss of RGCs by cell death (Villegas-Pérez et al., 1988, 1992), the number of L1 mRNA-containing RGCs fell (Figs. $3 \mathrm{a}$ and $3 \mathrm{~b}$ ). When set in relation to the number in normal rats, L1 mRNA-producing RGCs were $69 \%$ at 5 days, $44 \%$ at 7 days, $17 \%$ at 14 days, $10 \%$ at 21 days, and $12 \%$ at 28 days after ONL (Fig. 4a). These ratios are in accordance with earlier quantifications of surviving RGCs (Villegas-Pérez et al., 1988, 1992; Bähr et al., 1992).

RGCs with L1 mRNA were always more numerous than those containing GAP-43 mRNA (Fig. 3f), which in relation to the L1 mRNA-producing RGCs (in normal rats) were $2 \%$ at 2 days, $32 \%$ at 5 days, $10 \%$ at 7 days, $5 \%$ at 14 days, $1 \%$ at 21 days, and 0 at 28 days after ONL (Fig. 4a) and were thus similar to counts of GAP-43 protein-producing RGCs (Schaden et al., 1994).

Exposure of retinae to SC-1 antisense probes resulted in a mixture of heavily and weakly stained cells at 2 and 21 days (Figs. 3c and 3d) after ONL which hampered cell counts. Moreover, along with the reduction of RGC numbers, relatively small cells containing SC-1 mRNA and lying below the RGC layer became apparent.

To determine whether SC-1 mRNA is contained in RGCs after ONL, horseradish peroxidase (HRP) was applied to the optic nerve stump at the time of lesion. At 5 and 21 days after ONL, the corresponding retinae were processed to reveal RGCs labeled by HRP and those exhibiting the SC-1 in situ hybridization signal. Seventy percent of the HRP-labeled cells carried the in situ hybridization signal at 5 days, and these doublelabeled cells were $15 \%$ of the L1 mRNA exhibiting RGCs of the normal retina. At 21 days after ONL, HRP detection failed, probably because the enzyme had vanished from the RGCs. The larger size of the cells and their location in the RGC layer suggest that a few RGCs produced SC-1 mRNA (Fig. 3d) but no such cells were identified at 28 days after ONL. No RGCs displayed TAG-1 in situ hybridization signal after ONL (Fig. 3e).

In correlation with the loss of TAG-1 mRNA from axotomized RGCs, RGC axons gradually lost their anti-TAG-1 immunoreactivity. The axons present in the retina at the times analyzed were visualized by neurofilament antibodies. Axonal surface staining by anti-TAG-1 was present at 2 and 5 days after ONL but was barely detectable at 21 days after ONL (Fig. 5). As was expected from the presence of L1 mRNA in axotomized and surviving RGCs (Figs. 3a and 3b), the intraretinal axons continued to be anti-L1 immunoreactive during the period considered (Fig. 5). That a substantial proportion of surviving RGCs produce and transport GAP-43 into their axons was demonstrated earlier (Doster et al., 1991; Schaden et al., 1994) and was confirmed here.

Thus, the lesion-induced changes of mRNA synthesis in RGCs differ for each mRNA and protein under consideration. While synthesis of TAG-1 mRNA ceases directly after lesion, that of L1 mRNA continues in most or perhaps all RGCs that survive. RGCs which synthesize SC-1 mRNA represent a fraction of L1 mRNAcontaining RGCs at the time points considered, but they are absent at 28 days. RGCs that upregulate synthesis of GAP-43 mRNA are also a fraction, but while GAP-43 mRNA-synthesizing RGCs increase in number between 2 and 5 days and decrease thereafter (Fig. 4a), numbers of SC-1 mRNA-producing RGCs decline progressively.

FIG. 1. Detection of L1, SC-1, and TAG-1 mRNAs during development by in situ hybridization. (a, d, and g) Cross section through the eyes of E16 rat embryos, with the lens to the left and the optic nerve to the right. The intense in situ hybridization signals in the RGC layer indicate the presence of L1 (a) and TAG-1 (g) mRNAs. In situ hybridization signal was not detected with the antisense cRNA probe of SC-1 (d). (b, e, and h) Portions of retina wholemounts obtained from postnatal P15 rats. In situ hybridization signals are detected in RGCs with antisense cRNA probes of L1 (b), SC-1 (e), and TAG-1 (h). Most or all RGCs contain L1 mRNA (b) and TAG-1 mRNA (h). In the case of TAG-1 (h) and SC-1 (e) the intensity of the in situ hybridization signal varies over the RGC population. With the antisense SC-1 cRNA probe, several RGCs are heavily stained and others more 

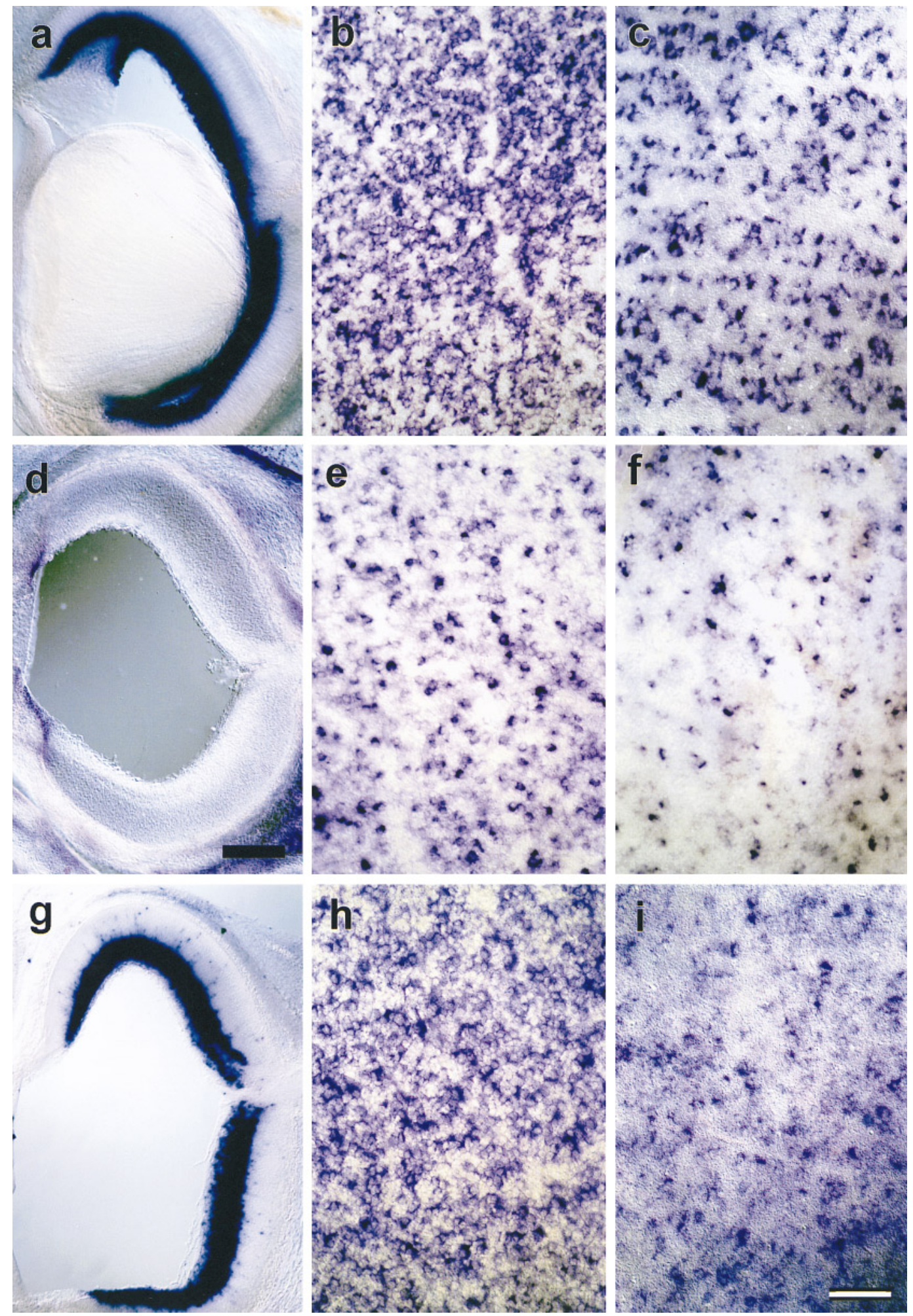

weakly. (c, f, and i) Portions of retina wholemounts from adult rats. In situ hybridization signal is still intense in many or all RGCs with the antisense L1 cRNA probe (c). With the antisense TAG-1 cRNA probe, there is a mixture of heavily and weakly stained RGCs (i). Only a few RGCs exhibit intense signal with the antisense SC-1 cRNA probe (f). Scale bar in d represents $120 \mu \mathrm{m}$ for a, $d$, and $g$, and scale bar in i represents $60 \mu \mathrm{m}$ for $b, c, e, f, h$, and i. 

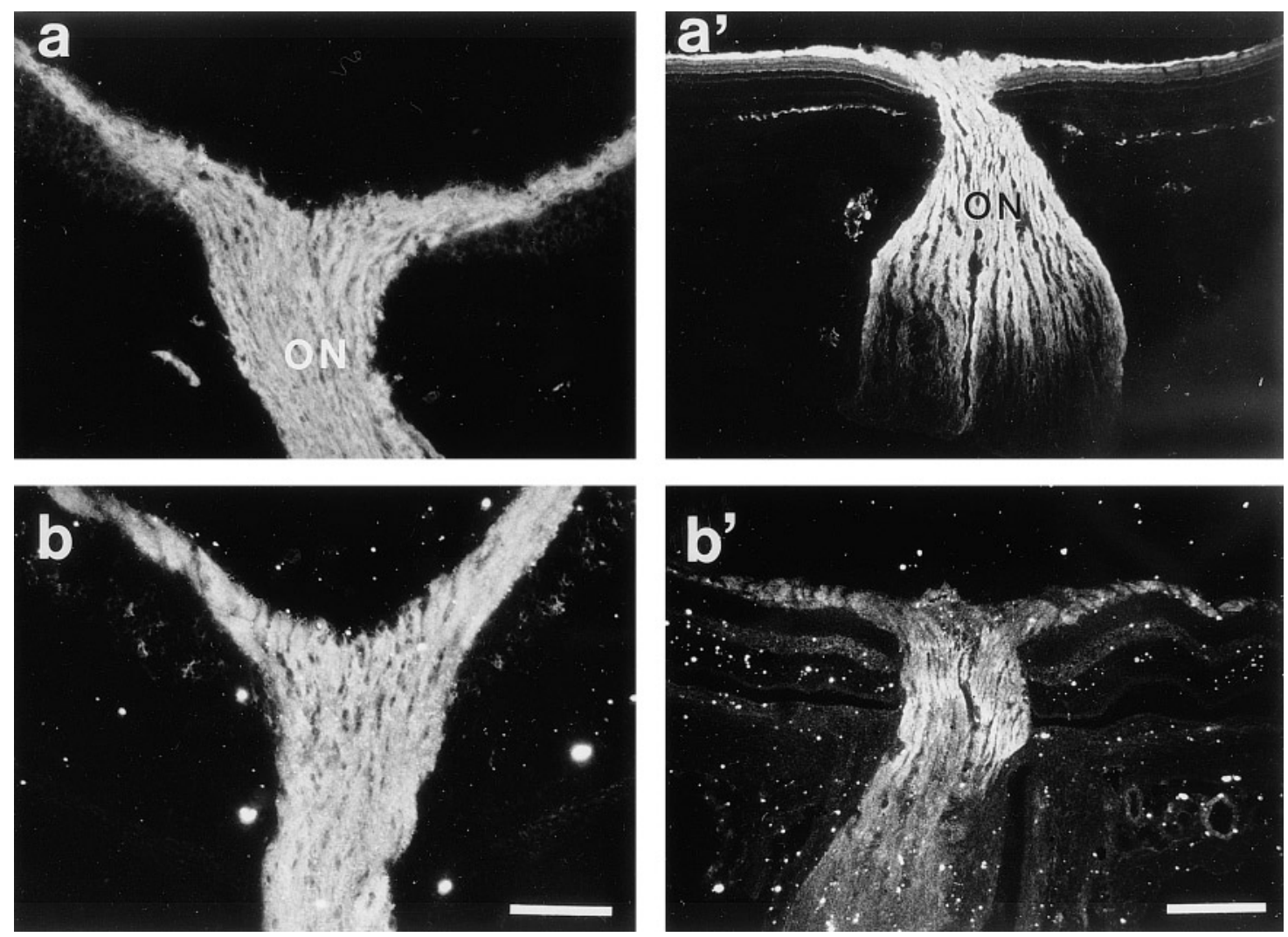

FIG. 2. Immunohistochemical localization of L1 and TAG-1 proteins on the RGC axonal surface. (a and b) E16 embryos; (a' and b') adult rat. Sections through the retina and optic nerve head (ON) after exposure to antibodies against L1 (a, $\left.\mathrm{a}^{\prime}\right)$ and TAG-1 (b,b') exhibit labeling of RGC axons in the retina and optic nerve. Anti-L1 labeling decreases along the ON. Scale bars in b and b', 100 and $200 \mu \mathrm{m}$, respectively.

\section{L1, SC-1, and TAG-1 during RGC Axon Regeneration Following Sciatic Nerve Transplantation}

Grafted rats whose retinae were subjected to the in situ hybridization procedure received an injection of HRP into the graft 3-4 days prior to sacrifice, to backlabel those RGCs that had regenerated an axon into the graft. In situ hybridizations with the antisense L1 cRNA probe revealed intensely stained RGCs, a substantial proportion of which contained HRP (Fig. 6).

These L1 mRNA-producing RGCs and HRP-labeled RGCs were quantified and set in relation to L1 mRNAcontaining RGCs in the normal retina, henceforth called reference. RGCs containing L1 mRNA in grafted rats were $5.2 \%$ of the reference and those also carrying HRP label were $3.9 \%$ of the reference (Fig. $4 \mathrm{~b}$ ).

In experiments with L1, all HRP-labeled RGCs contained L1 mRNA (Fig. 6b). RGCs with the L1 in situ hybridization signal alone had no HRP, either because the HRP uptake and transport was insufficient or be- cause they had no axons in the graft. The presence of double-labeled cells, however, allows the conclusion that axon-regenerating RGCs synthesize L1 mRNA.

RGCs producing GAP-43 mRNA in grafted rats (Fig. 6a) were $4.6 \%$ of the reference and those that were double labeled (HRP and the in situ signal) amounted to $3.2 \%$ of the reference (Fig. $4 \mathrm{~b}$ ). The in situ hybridization signal but no HRP was carried by $1.3 \%$, and $0.3 \%$ were HRP-labeled only. In other words, a small fraction of RGCs with regenerating axons in the graft do not or perhaps no longer synthesize GAP-43 mRNA, and there is a fraction of GAP-43 mRNA-producing RGCs which may or may not have an axon. However, most axonregenerating RGCs (double-labeled cells) produce GAP-43 mRNA. Numbers of double-labeled RGCs in experiments with antisense GAP-43 and L1 cRNA are similar (Fig. $4 b)$ and statistically not different $(\alpha<0.01)$. Results therefore indicate that most axon-regenerating RGCs in grafted rats synthesize both L1 and GAP-43 mRNAs.

In retinae of grafted rats subjected to in situ hybridiza- 

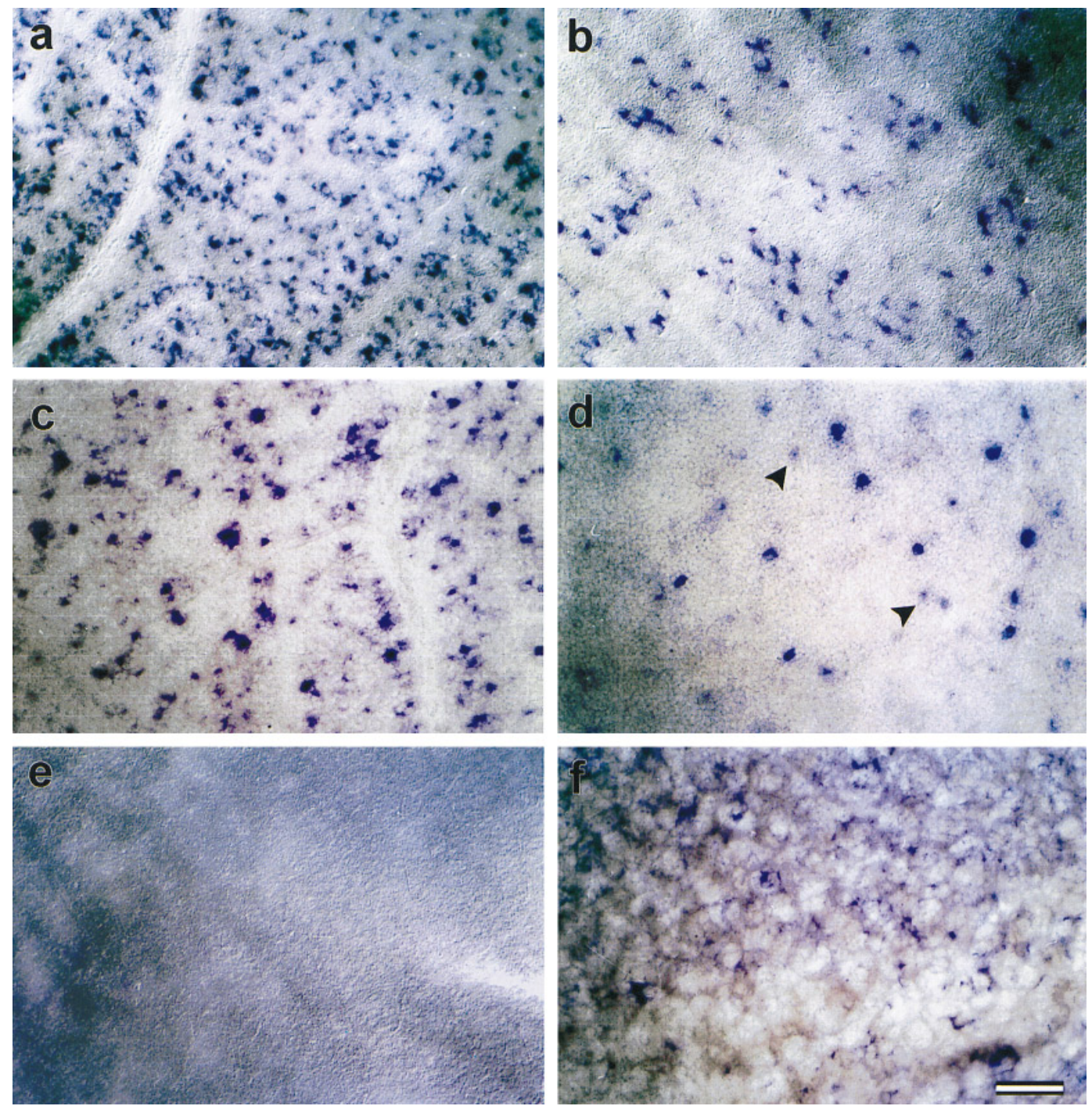

FIG. 3. Detection of L1, SC-1, and TAG-1 mRNAs by in situ hybridization on retina wholemounts after ONL. (a, c, e, and f) 2 days after ONL; (b and d) 21 days after ONL. In situ hybridization signals continue to be present in many RGCs at 2 days after ONL in the case of L1 and SC-1 cRNA probes $(\mathrm{a}, \mathrm{c})$, are not detected with the TAG-1 cRNA probe (e), but begin to appear with the GAP-43 cRNA probe (f). After massive lesion-induced RGC death, many or all of the surviving RGCs at 21 days after ONL continue to exhibit in situ hybridization signals with the antisense L1 cRNA probes (b). With the antisense SC-1 cRNA probe (d) a few large cells in the RGC layer and smaller cells in the layer below the RGC layer are stained (arrowheads). In situ hybridization signals were not present with the antisense TAG-1 cRNA probe. Scale bar, $60 \mu \mathrm{m}$.

tion with SC-1 antisense cRNA probes, HRP-labeled RGCs were present in similar numbers to those in the foregoing experiments (4\%) but none of the HRPlabeled RGCs carried the SC-1 in situ hybridization signal (Fig. 6c). That the in situ hybridization procedure was successful is demonstrated by the presence of stained cells in a focal plane below the RGC layer. With TAG-1 antisense cRNA probes, none of the HRP-labeled or unlabeled RGCs carried an in situ hybridization signal (Fig. 6d). We therefore conclude that RGCs entertain regenerating axons in the graft without synthesizing SC-1 or TAG-1 mRNAs.

To determine whether regenerating RGC axons in the graft display the corresponding proteins, longitudinal sections through the graft were exposed to the relevant antibodies. Control experiments, in which RGC axons were prevented from growing into the graft, showed that axons from other sources (for example, those innervating eye muscles) enter the graft. Such axons, as well as Schwann cells, are anti-L1 (Seilheimer and 

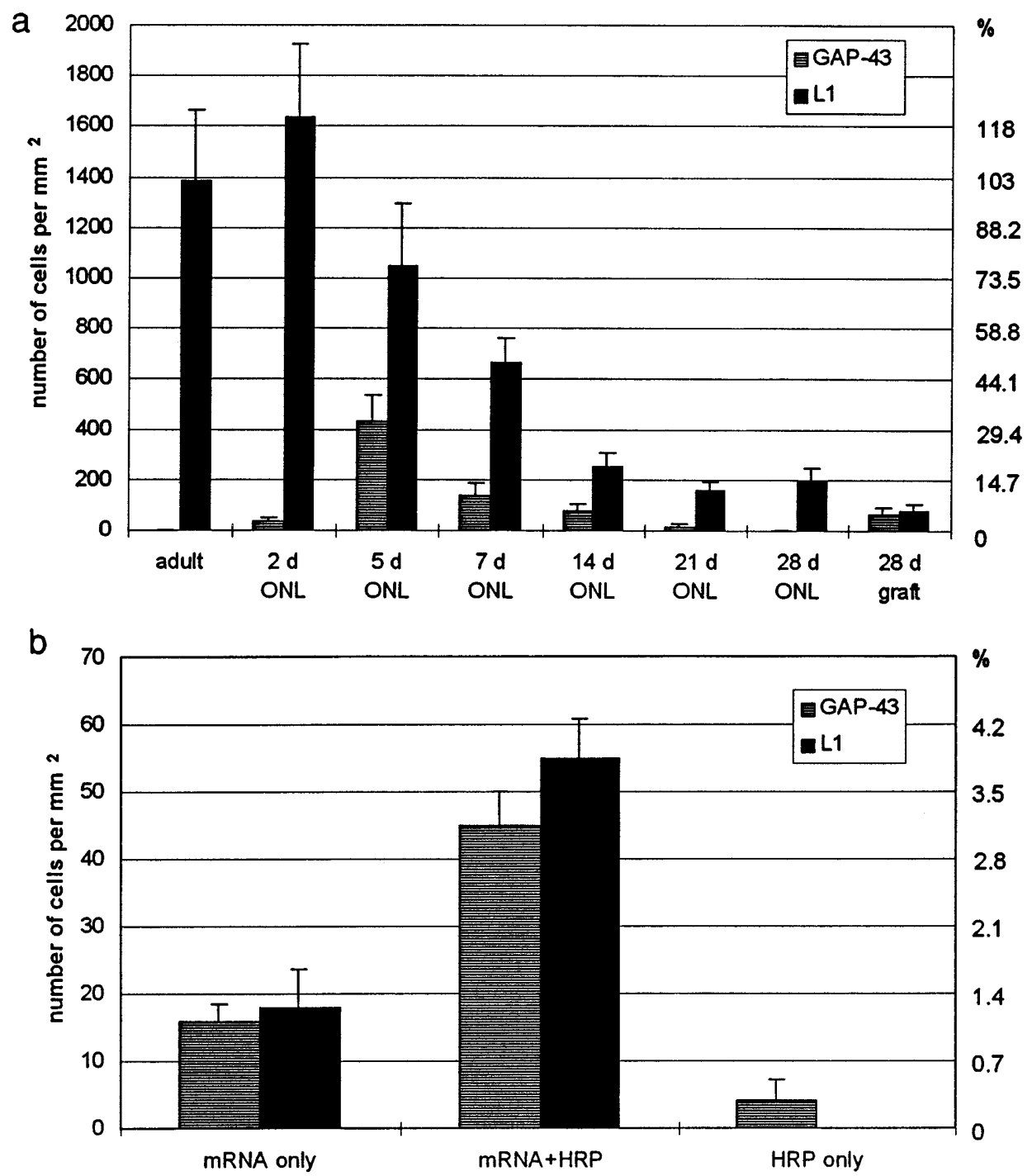

FIG. 4. (a) Quantification of RGCs displaying in situ hybridization signals with antisense cRNA probes of L1 and GAP-43, in the normal adult retina and in retinae between 2 and 28 days after ONL. The height of the bars indicates the average number of stained RGCs and the standard deviation. At all times examined many or all of the surviving RGCs contained L1 mRNA. RGCs containing GAP-43 mRNA are only a fraction of those exhibiting L1 mRNA. RGCs in grafted rats (28-day graft) contain GAP-43 and L1 mRNAs and are also shown in Fig. 5b. (b) Quantification of RGCs in grafted rats displaying the GAP-43 and L1 mRNAs and backlabeled with HRP. The height of the bars represents number of labeled RGCs and the standard deviation. RGCs carrying both the in situ hybridization signal and HRP (mRNA and HRP) and those with HRP only represent RGCs with regenerating axons in the graft. A fraction of RGCs present in retinae of grafted rats exhibit mRNAs but no HRP (first pair of bars).

Schachner, 1988; Dezawa and Magano, 1996) and -GAP-43 (Curtis et al., 1992) immunoreactive (Fig. 7). Grafted rats therefore received an intraocular injection of biotin 3 days prior to sacrifice. This allowed us to identify regenerating retinal axons in the graft and to determine whether the forward-labeled RGC axons exhibit anti-L1, anti-GAP-43, and anti-TAG-1 immunoreactivity.

Labeled RGC axons in the graft were anti-L1 (Figs. 7a and $\left.7 a^{\prime}\right)$ and, as expected from earlier results (Doster $e t$ al., 1991; Schaden et al., 1994), anti-GAP-43 immunopositive (Figs. $7 \mathrm{~b}$ and $7 b^{\prime}$ ). Regenerating RGC axons in the graft were not labeled by anti-TAG-1 (Figs. 7c and 7c'). Since no reliable antibodies against SC-1 were available, the presence or absence of protein could not be determined, but the absence of SC-1 mRNA from RGCs suggests that $\mathrm{SC}-1$ protein is not present on regenerating axons.

When retina segments of adult rats ( 7 days after a conditioning optic nerve crush) are explanted on a laminin 

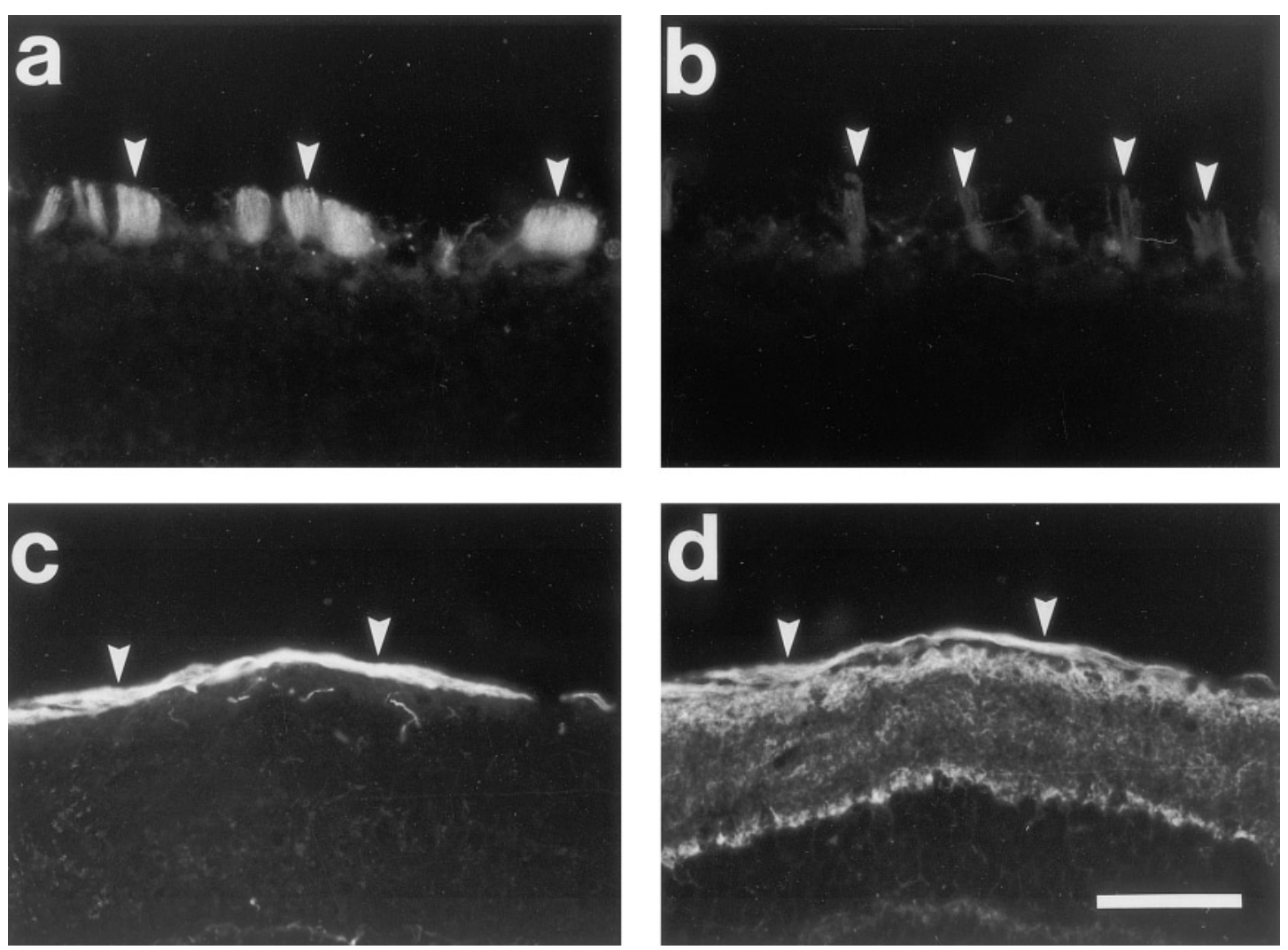

FIG. 5. Immunohistochemistry with TAG-1 and L-1 antibodies on axotomized RGC axons in the retina. (a and b) Transverse sections of retina. RGC axons (associated into bundles, arrowheads) in the retina are labeled by anti-TAG-1, more intensely at 2 days (a) than at 21 days after ONL (b), when labeling is barely above detection level. (c and d) The persisting RGC axons (arrowheads) at 21 days after ONL are revealed by anti-neurofilament staining (c), and these axons (arrowheads in c,d) are also labeled by anti-L1 (d). Scale bar, $50 \mu \mathrm{m}$.

substrate, they successfully extend RGC axons (Bähr et al., 1988). These axons (at Day 6-7) in culture are not only anti-GAP-43 and -L1 positive, but are also brightly labeled by TAG-1 antibody (Fig. 8a), in contrast to regenerating axons in vivo. Since this indicates an upregulation of TAG-1 by axon-regenerating RGCs in vitro, the explants were subjected to in situ hybridization with the TAG-1 antisense probe. As documented in Fig. 8b, these explants contained cells with TAG-1 mRNA in the RGC layer. SC-1 mRNA was also found in retinal explants; however, since the explants flatten out, we were not able to determine whether the stained cells are RGCs or cells in the layer deep to the RGCs.

The observations on TAG-1 in culture suggest that TAG-1 synthesis may be repressed in vivo but induced under in vitro conditions.

\section{DISCUSSION}

In neurons which regenerate axons, one would expect to find many of the molecules known to be associated with aspects of axon development. Three such molecules are the IgSF CAMs TAG-1, SC-1, and L1. Of these, only L1 was present in axon-regenerating RGCs of the rat. All three CAMs were produced by RGCs at some stage during development: L1 and TAG-1 in the embryo when RGCs extend axons, and SC- 1 by the day of birth. This suggests that they are associated with aspects of RGC axon development and hence probably needed during axon regeneration. Synthesis of all three CAMs persists into adulthood but axotomy apparently disrupts production of TAG-1 and SC- 1 mRNAs: Optic nerve lesion causes loss of TAG- 1 mRNA within 2 days and a gradual reduction of RGCs with SC- 1 mRNA. This lesion-induced loss of mRNA cannot be overcome by the presence of the PNS graft. RGCs in grafted rats showed no TAG-1 or SC-1 in situ hybridization signal, and axons were anti-TAG-1 negative. Axotomy did not negatively influence L1 synthesis: L1 remained present in many and perhaps all RGCs that survived. Thus, RGCs that regenerate axons synthesize L1, but fail to upregulate SC-1 and TAG-1. Together with L1, these 

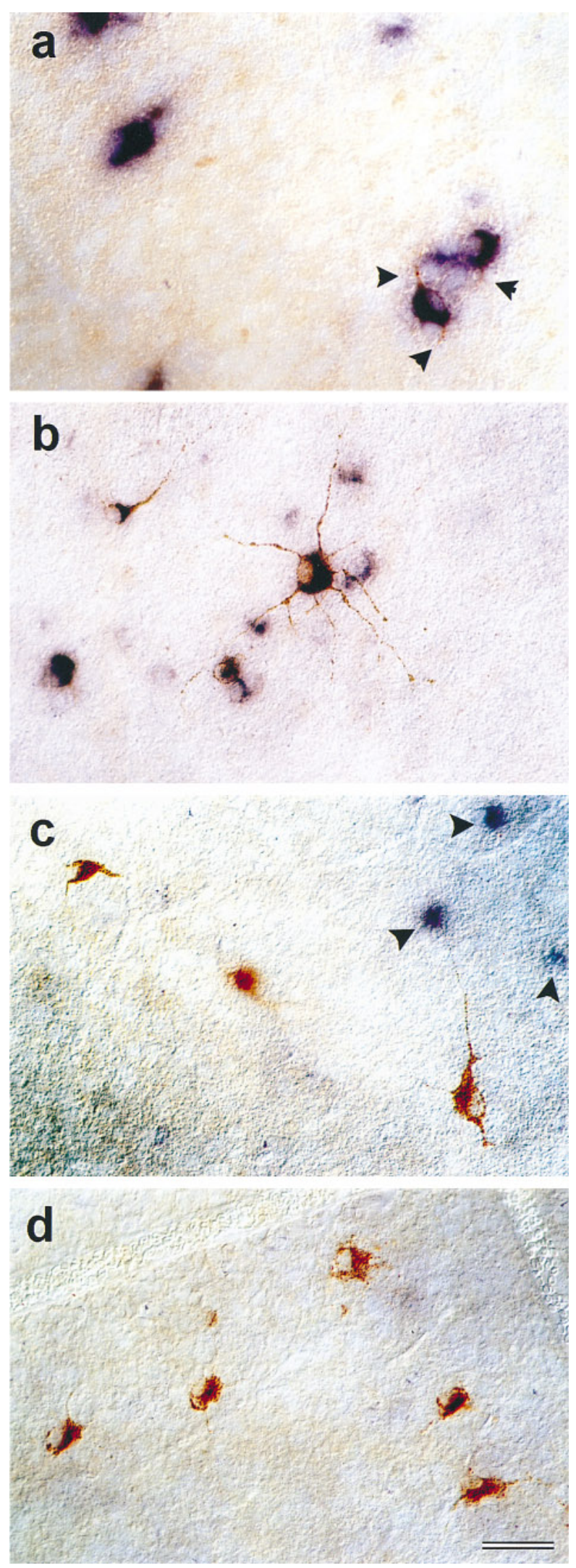

RGCs produce GAP-43, which is upregulated in a proportion of RGCs upon axotomy (Doster et al., 1991; Schaden et al., 1994).

The present results rely on the detection of mRNAs by the nonradioactive in situ hybridization procedure with riboprobes derived from rat $\mathrm{cDNAs}$ and on localization of the relevant proteins (except SC-1, see below) by antibodies, whose specificity was confirmed by Western blots (Karagogeos et al., 1991; Shreyer and Skene, 1991; Rathjen and Schachner, 1984; and Experimental Methods). Both methods are suited for detection of significant amounts of mRNAs and proteins and generally gave congruent results concerning presence or apparent absence of GAP-43, L1, and TAG-1. This also excludes the possibility that adult regenerating axons express variants of the embryonic proteins which might escape detection when an epitope-specific monoclonal antibody is used (Bates and Meyer, 1997). That RGC axons were still weakly anti-TAG-1 immunofluorescent 3 weeks after ONL when TAG-1 mRNA was long since undetectable can be explained by the slow turnover rate of TAG-1 protein in the axonal membrane, proposed to be characteristic of GPI-linked proteins (Lemanski et al., 1990). The quantification of L1 mRNA containing RGCs suggests that most or even all RGCs surviving axotomy express L1 mRNA. Therefore it seems reasonable to compare axon-regenerating RGCs with L1 mRNAsynthesizing RGCs in the normal retina, because they represent a population of RGCs capable of synthesizing at least one CAM.

The time point of analysis, 28 days after surgical graft attachment, seems appropriate for tests of presence or absence of CAMs because regenerating RGC axons approach the distal end of the graft around this time and thus are growing (see McKerracher et al., 1990). The corresponding RGCs are therefore expected to keep up the production of mRNAs and proteins (including CAMs) associated with axon growth at the time of our

FIG. 6. In situ hybridizations on retina wholemounts obtained from grafted rats, after HRP application to the regenerating axons in the graft. RGCs retrogradely labeled by HRP appear reddish-brown; the in situ hybridization signal appears blue or black. (a and b) With antisense L1 (b) and GAP-43 (a) cRNA probes many of the RGCs present display the in situ hybridization signal in their somata while HRP also extends into their dendrites. Examples are marked by arrowheads in (a). (c) With the antisense SC-1 cRNA probe, small cells below the RGC layer (arrowheads) display the in situ hybridization signal. HRP is present in RGCs which do not contain the in situ hybridization signal. (d) With the antisense TAG-1 cRNA probe, no RGCs were found containing the signal, but HRP-labeled RGCs were present. Scale bar, $30 \mu \mathrm{m}$. 

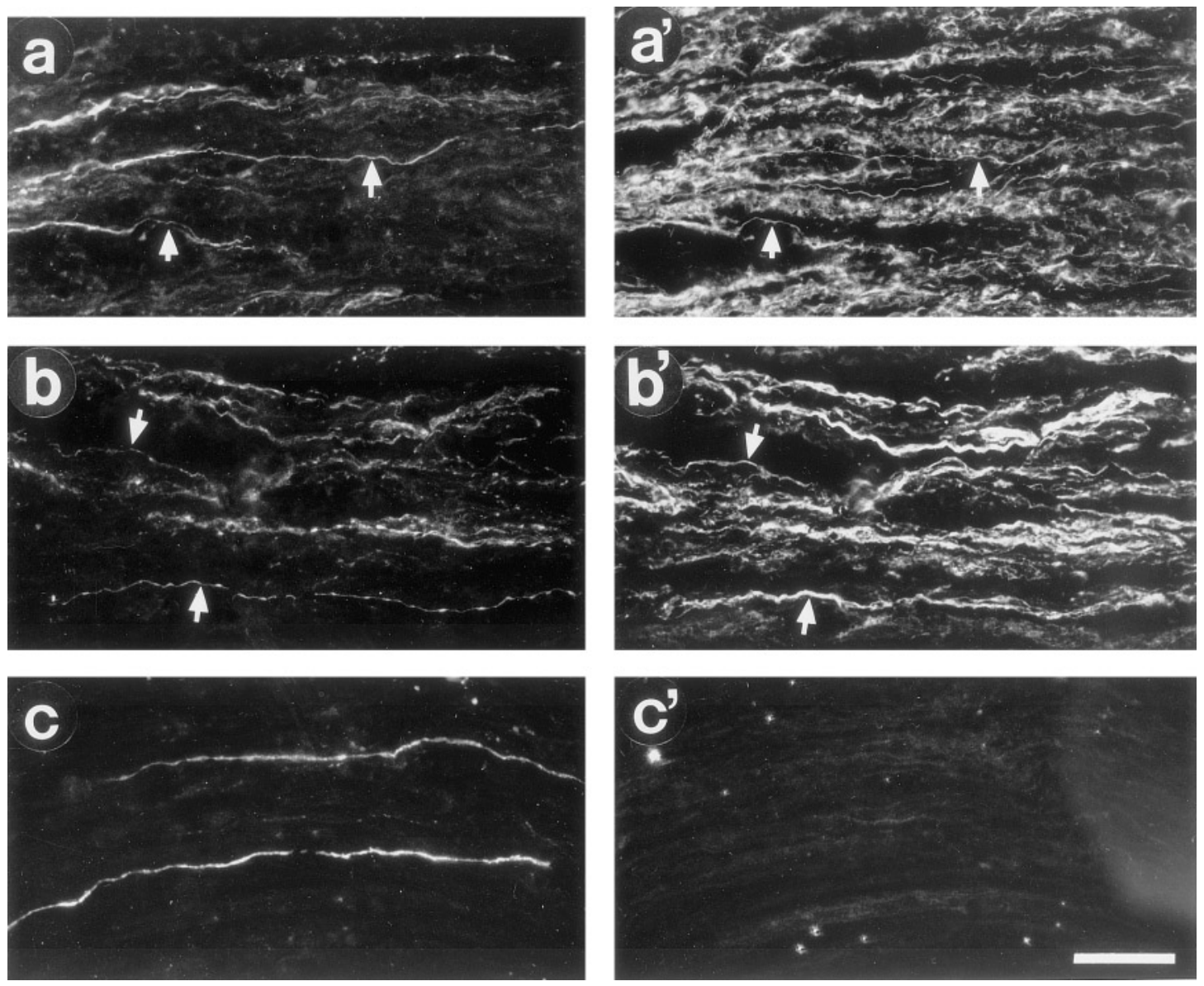

FIG. 7. Immunohistochemistry with antibodies against L1, GAP-43, and TAG-1 on longitudinal sections through the sciatic nerve graft. Regenerating RGC axons are identified by their content of biotin ( $\mathrm{a}, \mathrm{b}$, and $\mathrm{c})$ and examples are marked by arrows. Biotin-labeled axons are anti-L1 positive ( $\mathrm{a}^{\prime}$, arrows) and anti-GAP-43 positive ( $\mathrm{b}^{\prime}$, arrows). Axons not containing biotin labeling and Schwann cells are also labeled. ( $\mathrm{c}^{\prime}$ ) Anti-TAG-1 immunoreactivity is not found, either on RGC axons or on other structures of the graft. Scale bar, $50 \mu \mathrm{m}$.

analysis. We would not expect a transient increase and decrease of mRNA and protein production by RGCs between 0 and 28 days after grafting although we cannot exclude this possibility.

The number of RGCs in grafted rats backfilled with HRP, and thereby identified as RGCs with regenerating axons (about $4 \%$ ), roughly corresponds to the number of axon-regenerating RGCs determined in earlier studies (4.7\%, Villegas-Pérez et al., 1992; \% , Schaden et al., 1994) where other retrograde tracers were used. HRP is not a quantitative marker but can be combined with in situ hybridization, and thus allows a good estimate of the number of RGCs regenerating axons and producing mRNA. That the number of RGCs producing GAP-43 mRNA and L1 mRNA in grafted rats is higher than the number of cells containing both mRNA and HRP label may result from insufficient HRP uptake or transport by axons or perhaps these RGCs produce the mRNAs but fail to regenerate axons. A few RGCs contained HRP but no GAP-43 mRNA, suggesting that mRNA detection may have failed or that RGCs have downregulated GAP-43 mRNA. Finding HRP preferentially in RGCs displaying the L1 or GAP-43 in situ hybridization signal argues against the possibility that HRP applied to the graft diffuses freely into the retina and labels RGCs nonspecifically.

When HRP is applied to the graft, the regenerating axons are severed. It is possible that this axotomy induces mRNA and protein production in RGCs, for instance, of GAP-43. L1 mRNA was present in uninjured as well as in axotomized RGCs, and no dramatic change caused by the second insult was apparent, nor was there a change concerning TAG-1 and SC- 1 mRNAs. Moreover, GAP-43 and L1 proteins were present in regenerat- 

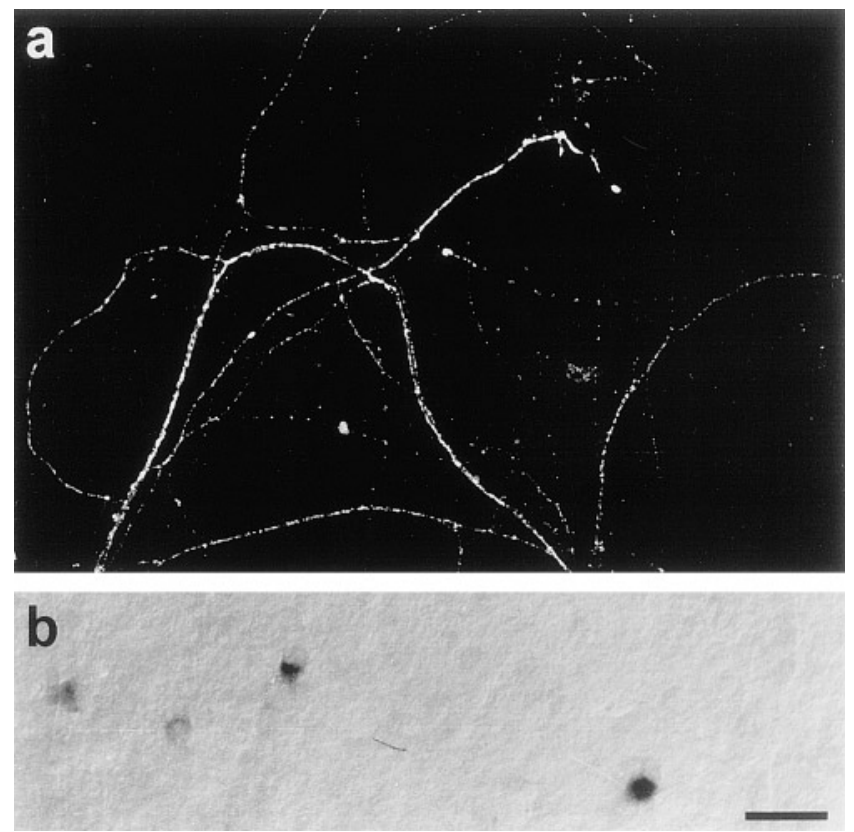

FIG. 8. Explants of adult rat retina in culture. (a) RGC axons extending from the explant are anti-TAG-1 immunoreactive. (b) RGCs in the explants exhibit the in situ hybridization signal with the antisense TAG-1 cRNA probe. Scale bar in b, $100 \mu \mathrm{m}$ for a and $50 \mu \mathrm{m}$ for $b$.

ing axons in the graft-which were not axotomized again-and TAG-1 protein was absent. These considerations speak for the validity of our conclusion concerning the presence or absence of specific CAMs in axonregenerating RGCs. Further support comes from analysis of earlier sets of retinae in grafted rats which were subjected to in situ hybridization without the insertion of HRP. These retinae had a number of GAP-43 and L1 mRNA-containing RGCs similar to that of retinae with HRP-labeled RGCs.

The loss of TAG- 1 mRNA from RGCs at 2 days after ONL, the progressive loss of RGCs containing SC-1 mRNA and the continuous presence of L1 mRNA shows that each mRNA is regulated differently. GAP-43 mRNA regulation again differs from that of the CAMs (Skene, 1989; Doster et al., 1991; Schaden et al., 1994). This situation in rats contrasts to that observed in fish where all these mRNAs and proteins are dramatically upregulated after ONL and where they remain elevated during axon regeneration (reviewed in Stuermer et al., 1992; Bernhard et al., 1996; Giordano et al., 1997; D. Lang and C. A. O. Stuermer, unpublished results). This was one reason why L1, TAG-1, and SC-1 were selected for tests of CAM synthesis by axon-regenerating rat RGCs. Moreover, related proteins and direct homologs in various species have been demonstrated to be involved in axon elongation, recognition, fasciculation, and contact stabilization (i.e., TAG-1 in mouse: Furley et al., 1990; axonin-1 in chick: Ruegg et al., 1989; Stoeckli et al., 1991; L1 in mouse and rat: Bartsch et al., 1989; Mohajeri et al., 1996; Stallcup and Beasley, 1985; NgCAM in chick: Lemmon et al., 1989; Chang et al., 1987; Rathjen et al., 1987; Yamagata et al., 1995; E587 antigen in goldfish: Bastmeyer et al., 1995; SC-1/DM-GRASP in chick: Burns et al., 1991; Tanaka et al., 1991; Pollerberg and Mack, 1994; Yamagata et al., 1995; neurolin in goldfish: Bastmeyer et al., 1996). Moreover, CAMs activate signal transduction pathways which effect and modulate axon growth (Doherty and Walsh, 1994; Kunz et al., 1996). Their presence in embryos and postnatal rats suggests that these CAMs contribute similarly to aspects of RGC axon growth and stabilization in rats. Axon-regenerating rat RGCs, however, produce L1, but neither TAG-1 or SC-1.

Our conclusion that RGC axon regeneration in grafted rats takes place not only in the absence of TAG-1 but also in the absence of SC- 1 is based on mRNA detection alone, since antibodies against the SC-1 mRNA-derived protein of RGCs were not available. Results from several authors suggest that the nervous system possesses variants of SC-1 protein. Antibody F.84.1 (Prince et al., 1992) and several monoclonal antibodies against SC-1/ DM-GRASP stain motoneurons and cranial nerves (Burns et al., 1991; Tanaka et al., 1991) but not retinal axons (De Bernado and Chang, 1996), whereas a polyclonal antiserum against a chick protein whose $\mathrm{N}$-terminal sequence is identical to DM-GRASP labeled retinal axons and inhibited retinal axon growth (Pollerberg and Mack, 1994). Chick SC-1 and neurolin, the SC-1 homo$\log$ in fish, are found not only on growing RGC axons but also in the layer of the optic tectum where axons form terminal arbors and synapses with target neurons (Paschke et al., 1992; Yamagata et al., 1995). Detection of SC-1 mRNA at the day of birth could indicate involvement of SC-1 during rat RGC axon arbor development, remodeling, and stabilization as was suggested for fish and chick. In this context it will be interesting to investigate whether SC-1 mRNA reappears in RGCs when regenerating rat RGC axons are given the opportunity to form synapses with target neurons, as occurs when the sciatic nerve is implanted into the brain (Vidal-Sanz et al., 1987).

L1 on the Schwann cell surface is one of the proteins stimulating growth cone elongation (Seilheimer and Schachner, 1988) and L1-L1 interactions are likely to contribute to RGC regeneration in the graft. SC-1/DMGRASP and TAG-1/axonin-1 were reported to interact 
homophilically (Burns et al., 1991; Rader et al., 1993) as well as heterophilically with L1/NgCAM (De Bernado and Chang, 1996; Felsenfeld et al., 1994; Kuhn et al., 1991). Such and further interactions mediated by rat L1, SC-1, and TAG-1 could conceivably enhance rat RGC axon regeneration. Their absence from RGCs during axon regrowth through the graft may impair the efficacy of RGC axon regeneration. It has recently been demonstrated that regenerating RGC axons of mice continue to express specific integrins which allow embryonic axons to extend on laminin. These integrins, however, lost their function as laminin receptors in adult regenerating axons, suggesting that regenerating axons use a different and unidentified receptor for their growth on laminin (Bates and Meyer, 1997). Therefore, it is possible that lost functions-in consequence of downregulation or inactivation of specific axonal receptors-are taken over by other proteins which are expressed during regeneration.

Downregulation of TAG-1 and SC-1 is apparently caused by axotomy-induced conditions, which are not compensated by the positive influence of the graft and its Schwann cells (Bunge and Hopkins, 1990). It has been suggested that CNS neurons-in contrast to PNS neurons-may be incapable of reinducing TAG-1 production (Karagogeos et al., 1991). Our findings show that rat RGCs in retinal explants in vitro and axotomized RGCs in fish produce TAG-1 mRNA (D. Lang and C. A. O. Stuermer, unpublished results). It is conceivable that the environment of the neurons and their axons has an influence on up- or downregulation of specific proteins (Bartsch et al., 1989; Skene, 1991). The finding that rat RGCs produce TAG-1 mRNA in culture but not in vivo speaks for the view that TAG-1 expression in vivo is inhibited. Such repression appears not to exist in fish, where axon regeneration by RGCs is both qualitatively and quantitatively superior to that in all other vertebrates considered to date (Gaze, 1970; Grafstein, 1986). In summary, axotomized RGCs in rats can regenerate axons in the absence of the CAMs TAG- 1 and SC- 1 but robust axon growth as is observed in fish and rat embryos may require the presence of these CAMs and other growth-related proteins.

\section{EXPERIMENTAL METHODS}

Surgery. Adult female Wistar rats weighing 250-300 $\mathrm{g}$ were anesthetized by intraperitoneal injection of Kemint/Rompun (Alvetra/Bayer; $0.25 \mathrm{ml}$ Kemint/0.05 $\mathrm{ml}$ Rompun per $300 \mathrm{~g}$ body weight) for all surgical procedures including intravitreal injections. All surgery was in compliance with animal welfare legislation. In one group of rats, the left optic nerve was either crushed or cut as described by Doster et al. (1991) to analyze the changes of mRNA and protein production in RGCs at 2, $5,7,14,21$, and 28 days after ONL. To identify RGCs among other retinal cells expressing SC-1 mRNA (see below) in this group of rats, crystals of HRP (type VI; Sigma) were applied to the orbital stump of the cut optic nerve. In a second group of rats (grafted rats) an autologous sciatic nerve segment was attached to the orbital stump of the transected optic nerve according to procedures by Villegas-Pérez et al. (1988). Grafted rats were sacrificed 28 days after surgery. The retinae of all operated rats were examined ophthalmoscopically and those with signs of vascular damage were discarded.

Grafted rats and rats after unilateral optic nerve crush/cut as well as normal rats were used for either immunohistochemistry or in situ hybridization experiments. Grafted rats for immunohistochemistry received an intraocular injection of $5 \mu \mathrm{l} n$-hydroxysuccinimidobiotinester [Sigma; $0.5 \mathrm{mg}$ in $10 \mu \mathrm{l}$ ethanol plus $10 \mu \mathrm{l}$ DMSO (Halfter, 1987)] 2 days before sacrifice to anterogradely label regenerating RGC axons in the graft. This was necessary to identify RGC axons because axons from other sources grow into the graft, and they as well as processes of PNS glia cells are immunoreactive with the antibodies used in this study (see below).

For in situ hybridization experiments on grafted rats, HRP was applied to an incision in the graft 3-4 days before sacrifice to label RGCs with regenerating axons.

Antibody labeling. Antibody labeling was performed on 10- $\mu \mathrm{m}$ cryostat sections. Cross sections were made through the heads of E16 rat embryos and through the eyes of adult rats after removal of the lens and vitreus. Longitudinal sections of the grafted sciatic nerves with the eye attached were obtained. All tissue (unfixed) was briefly immersed in Tissue Tek (Miles) and frozen in liquid nitrogen. Cryostat sections were collected on SuperFrost/Plus-coated slides (Menzel), air dried at room temperature $(1 \mathrm{~h})$, fixed in methanol $\left(-20^{\circ} \mathrm{C}, 5 \mathrm{~min}\right)$, rinsed in phosphate-buffered saline (PBS), and incubated with the primary antibody either $1.5 \mathrm{~h}$ at $37^{\circ} \mathrm{C}$ or overnight at $4^{\circ} \mathrm{C}$. After rinses in PBS sections were exposed to secondary fluorescent antibodies $\left(1.5 \mathrm{~h}, 37^{\circ} \mathrm{C}\right)$, rinsed again, coverslipped under Moviol (4-88, Hoechst), and examined with a Zeiss Axiophot equipped with the appropriate set of filters. For double labeling with anti-neurofilament antibodies and anti-TAG-1 (see below), sections were incubated in anti-TAG-1 and Cy3-conjugated secondary antibody donkey anti-mouse IgG, then incubated in anti-neurofilament antibody and subsequently exposed to FITC- 
conjugated secondary antibody. Sections were thoroughly rinsed in PBS between each incubation step. Incubation was for $1.5 \mathrm{~h}$ at $37^{\circ} \mathrm{C}$ for each antibody. Sections through eyes and grafts of grafted rats were incubated in AMCA-coupled avidin (in 1\% BSA in PBS) to visualize the anterograde tracer biotin $\left(1 \mathrm{~h}, 37^{\circ} \mathrm{C}\right)$ and then exposed to one of the antibodies against the axonal surface proteins specified below.

Retinal axons in culture were labeled by anti-TAG-1 and secondary antibody. Hanks' balanced salt solution (HBSS; Gibco, Eggenstein) with 10\% FCS was used to dilute antibodies and for washing steps. Axons were postfixed in 2\% PFA (paraformaldehyde) in PBS.

Antibodies. The following dilutions of antibodies (in PBS) were made: IgG fraction of an immune serum against mouse L1 (kindly provided by F. Rathjen) at a concentration of $1.6 \mu \mathrm{g} / \mathrm{ml}$; monoclonal antibody (Mab) 1 C12 (IgG) against rat TAG-1 (Dodd et al., 1988; kindly provided by D. Karagogeos) 1:10000; Mab 9-1E12 (IgG), ascites fluid against rat GAP-43 (Shreyer and Skene, 1991; kindly provided by D. Shreyer) 1:10000; Mab RT97, ascites fluid against phosphorylated neurofilaments (kindly provided by J. N. Wood) 1:2000; Mab NF-H (IgM) against phosphorylated neurofilaments (Pennypacker et al., 1991; kindly provided by P. Levitt) 1:100; and biotin-labeled antibodies against HRP (Dianova, Hamburg, Germany), 1:200. All secondary antibodies were purchased from Dianova: RITC-conjugated goat anti-rabbit IgG (1:200); Cy3-conjugated donkey anti-rabbit IgG (1:2000); Cy3-conjugated donkey antimouse IgG (1:2000), FITC-conjugated donkey antimouse IgM (1:200); FITC-conjugated donkey antimouse IgG (1:200). Immunoblots were performed with the antiserum against mouse L1 as described by Vielmetter et al. (1991) with detergent-extracted rat brain membrane proteins. The emerging bands at approximately 200, 140, and $80 \mathrm{kDa}$ were typical for L1 in rodents (Rathjen and Schachner, 1984; Prince et al., 1991).

Preparation of retinal explants. Seven days after optic nerve crush, the eye of adult rats was removed, briefly rinsed in $70 \%$ methanol and transferred to HBSS. The retina was isolated and attached by suction to a nylon filter (Hybond $\mathrm{N}^{+}$; Amersham) with the photoreceptor layer down. The basal lamina overlying the RGC layer was removed and retina and filter were cut into six pie-shaped pieces. These pieces were explanted onto poly-L-lysine- and laminin-coated petriperm dishes with the RGC layer down and cultured for 7 days in serumfree medium (DMEM; Gibco) at $37^{\circ} \mathrm{C}$ in the presence of $10 \% \mathrm{CO}_{2}$. The medium contained $0.4 \%$ methyl cellulose and supplements according to Needham (1987) but cholera toxin, endothelial mitogen, and transferrin were omitted and gentamycin was replaced by penicillin and streptomycin (Gibco).

Production of cRNA as hybridization probes and in situ hybridization. The following plasmids were used: pBKSII (-) containing a 1.6-kb insert of TAG-1 (kindly provided by A. J. W. Furley; Furley et al., 1990); pGEM-3 containing a 750-bp insert of GAP-43 (kindly provided by J. H. P. Skene); pBKSII(+) containing a 3.5-kb insert of SC-1 (kindly provided by T. M. Jessel); and pBKSII M 13 containing a 5.2-kb insert of NILE (kindly provided by W. Stallcup), the rat homolog of L1 (Bock et al., 1985; Prince et al., 1991). From the $5^{\prime}$ terminal region of NILE/L1 $1.3 \mathrm{~kb}$ was subcloned in pBSKII(+) using the unique sites of $\mathrm{BamHI} / \mathrm{XhoI}$. The plasmids were linearized with the appropriate restriction enzymes, treated with proteinase K (Boehringer Mannheim), extracted with phenol/chloroform, precipitated, and labeled by in vitro transcription with a digoxigenin (DIG)-RNA labeling kit (Boehringer Mannheim) using T3, T7, or SP6 RNA polymerases. The riboprobe of SC-1 was reduced to a mean size of $200 \mathrm{bp}$ by limited alkaline hydrolysis according to Wilkinson (1992). In situ hybridization was carried out on vibratome sections through the heads of embryos (E13-E19), retina wholemounts of postnatal P0-P15, and adult rats and retinal explants, essentially as described in Breitschopf et al. (1992) and Westerfield (1994). The heads of embryos were fixed in $4 \%$ PFA in PBS at $4^{\circ} \mathrm{C}$ for $6 \mathrm{~h}$, transferred to $30 \%$ sucrose in PBS overnight, embedded in $2 \%$ agarose (Gibco BRL), cut in $300-\mu \mathrm{m}$ transverse sections with a vibratome, dehydrated in methanol, stored at $-20^{\circ} \mathrm{C}$, and then subjected to in situ hybridization procedures. Retina wholemounts prepared as described above were divided into eight pie-shaped segments, fixed in $4 \%$ PFA in PBS at $4^{\circ} \mathrm{C}$ (overnight), and rinsed in PBS. The sections and wholemounts which were stored in methanol at $-20^{\circ} \mathrm{C}$ (at least $2 \mathrm{~h}$ ) were rehydrated at room temperature (RT), fixed with $4 \%$ PFA (in PBS), treated with proteinase $\mathrm{K}$ $(10 \mu \mathrm{g} / \mathrm{ml}, \mathrm{RT}, 10 \mathrm{~min})$, and fixed again in $4 \%$ PFA (in PBS). The sections and wholemounts were then prehybridized at $55^{\circ} \mathrm{C}$ for $2 \mathrm{~h}$ prior to overnight hybridization (at $55^{\circ} \mathrm{C}$ ) in $500 \mu \mathrm{l}$ hybridization buffer ( $50 \%$ formamide, $2 \times \mathrm{SSCT}, 10 \%$ dextran sulfae, and $1 \mathrm{mg} / \mathrm{ml}$ tRNA) containing the probe at concentrations ranging from 50 to $150 \mathrm{ng}$ per milliliter of hybridization buffer. The next day the tissue was washed at $55^{\circ} \mathrm{C}$ in $50 \%$ formamide, $2 \times$ SSCT; $2 \times$ SSCT; and subsequently in $0.2 \times$ SSCT. After a blocking step [PBST, 2\% sheep serum (Sigma), $2 \%$ goat serum (Vector Laboratories), $2 \mathrm{mg} / \mathrm{ml}$ bovine serum albumin (Sigma)], the tissue was incubated with anti-DIG-antibodies (1:2000 in PBST) for $2 \mathrm{~h}$ at room temperature and thoroughly washed in PBST prior to 
the signal detection with $\mathrm{BM}$ purple AP substrate (Boehringer Mannheim). Sections and wholemounts were mounted in Moviol. All in situ hybridizations were made as doublets with the antisense and sense probes as control. Signals were found with the antisense probe and the sense probe controls were void.

Labeled cells in retina wholemounts were counted over $101-\mathrm{mm}^{2}$ quadrants in 8 segments of equal size from the optic disk to the peripheral margin. Data were statistically analyzed using the Kolmogoroff-Smirnow test.

Detection of the retrograde marker HRP in combination with in situ hybridization. Retina wholemounts were carried through the in situ hybridization protocol, washed, and incubated overnight at $4^{\circ} \mathrm{C}$ with biotin-labeled antibodies against HRP. The biotin was detected with the $A B C$ kit and the diaminobenzidine detection kit (both Vector Laboratories, Burlingame, CA) as described in the manufacturer's instructions.

Data were collected from at least 4 adult rats for each mRNA, for each protein, and for each time point after ONL and after PNS grafting. This included 44 grafted rats. At least 2 embryos and postnatal rats were used for each mRNA and protein.

\section{ACKNOWLEDGMENTS}

The authors thank Marianne Wiechers for excellent technical assistance and Jörn E. Schröder for help with combining the in situ hybridization and HRP-labeling techniques, Richard Ankerhold for help with image processing at the computer, and Thomas Schulte for helpful comments on the manuscript. Mary Anne Cahill corrected the English. This work was supported by the International Spinal Research Trust, Deutsche Stiftung Querschnittlähmung, International Institute for Paraplegiology, and Bundesministerium für Bildung und Forschung.

\section{REFERENCES}

Aguayo, A. J., Rasminsky, M., Bray, G. M., Carbonetto, S., McKerracher, L., Villegas-Pérez, M. P., Vidal-Sanz, M., and Carter, D. A. (1991). Degenerative and regenerative responses of injured neurons in the central nervous system of adult mammals. Philos. Trans. $R$. Soc. London (Biol.) 331: 337-343.

Bähr, M., Vanselow, J., and Thanos, S. (1988). In vitro regeneration of adult rat ganglion cell axons from retinal explants. Exp. Brain Res. 73: 393-401.

Bähr, M., Eschweiler, G. E., and Wolburg, H. (1992). Precrushed sciatic nerve grafts enhance survival and axonal regrowth of retinal ganglion cells in adult rats. Exp. Neurol. 116: 13-22.

Bartsch, U., Kirchhoff, F., and Schachner, M. (1989). Immunohistochemical localization of the adhesion molecules L1, N-CAM, and MAG in the developing and adult optic nerve of mice. J. Comp. Neurol. 284: $451-462$.
Bastmeyer, M., Schlosshauer, B., and Stuermer, C. A. O. (1990). The spatiotemporal distribution of N-CAM in the retinotectal pathway of adult goldfish detected by the monoclonal antibody D3. Development 108: 299-311.

Bastmeyer, M., Bähr, M., and Stuermer, C. A. O. (1993). Fish optic nerve oligodendrocytes support axonal regeneration of fish and mammalian retinal ganglion cells. Glia 8: 1-12.

Bastmeyer, M., Ott, H., Leppert, C. A., and Stuermer, C. A. O. (1995). Fish E587 glycoprotein, a member of the L1 family of cell adhesion molecules, participates in axonal fasciculation and the age-related order of ganglion cell axons in the goldfish retina. J. Cell Biol. 130: 969-976.

Bastmeyer, M., Ott, H., Laessing, U., and Stuermer, C. A. O. (1996). Functional characterization of two cell adhesion molecules-the E587 antigen and neurolin-during zebrafish CNS development. Soc. Neurosci. Abstr. 22: 1714.

Bates, C. A., and Meyer, R. L. (1997). The neurite-promoting effect of laminin is mediated by different mechanisms in embryonic and adult regenerating mouse optic axons in vitro. Dev. Biol. 181: 91-101.

Benowitz, L. I., and Lewis, E. R. (1983). Increased transport of 44,000 to 49,000 -dalton acidic proteins during regeneration of the goldfish optic nerve: A two-dimensional gel analysis. J. Neurosci. 3: 21532163.

Bernhardt, R. R., Tongiorgi, E., Anzini, P., and Schachner, M. (1996). Increased expression of specific recognition molecules by retinal ganglion cells and by optic nerve glia accompanies the successful regeneration of retinal axons in adult zebrafish. J. Comp. Neurol. 376: 253-264.

Bock, E., Richter-Landsberg, C., Faissner, A., and Schachner, M. (1985). Demonstration of immunocytochemical identity between the nerve growth factor-inducible large external (NILE) glycoprotein and the cell adhesion molecule L1. EMBO J. 4: 2765-2768.

Breitschopf, H., Suchanek, G., Gould, R. M., Colman, D. R., and Lassmann, H. (1992). In situ hybridization with digoxigeninlabelled probed: Sensitive and reliable detection method applied to myelinating rat brain. Acta Neuropathol. 84: 581-587.

Brümmendorf, T., and Rathjen, F. G. (1994). Cell Adhesion Molecules. 1. Immunoglobulin Superfamily. Academic Press, London.

Brümmendorf, T., and Rathjen, F. G. (1996). Structure/function relationships of axon-associated adhesion receptors of the immunoglobulin superfamily. Curr. Opin. Neurobiol. 6: 584-593.

Bunge, R. P., and Hopkins, J. M. (1990). The role of peripheral and central neuroglia in neural regeneration in vertebrates. Semin. Neurosci. 2: 509-518.

Burns, F. R., von Kannen, S., Guy, L., Raper, J. A., Kamholz, J., and Chang, S. (1991). DM-GRASP, a novel immunoglobulin superfamily axonal surface protein that supports neurite extension. Neuron 7: 209-220.

Chang, S., Rathjen, F. G., and Raper, J. A. (1987). Extension of neurites on axons is impaired by antibodies against specific neural cell surface glycoproteins. J. Cell Biol. 104: 355-362.

Clarke, P. G. H. (1985). Neuronal death in the development of the vertebrate nervous system. Trends Neurosci. 8: 345-349.

Curtis, R., Stewart, H. J. S., Wilkin, G. P., Mirsky, R., and Jessen, K. R. (1992). GAP-43 is expressed by nonmyelin-forming Schwann cells of the PNS. J. Cell Biol. 116: 1455-1464.

David, S., and Aguayo, A. J. (1985). Axonal regeneration after crush injury of rat central nervous system fibres innervating peripheral nerve grafts. J. Neurocytol. 14: 1-12.

DeBernardo, A. P., and Chang, S. (1996). Heterophilic interactions of DM-GRASP: GRASP-NgCAM interactions involved in neurite extension. J. Cell Biol. 133: 657-666. 
Dezawa, M., and Nagano, T. (1996). Immunohistochemical localization of cell adhesion molecules and cell-cell contact proteins during regeneration of the rat optic nerve induced by sciatic nerve autotransplantation. Anat. Rec. 246: 114-126.

Dodd, J., Morton, S., Karagogeos, D., Yamamoto, M., and Jessell, T. M. (1988). Spatial regulation of axonal glycoprotein expression on subsets of embryonic spinal neurons. Neuron 1: 105-116.

Doherty, P., and Walsh, F. S. (1994). Signal transduction events underlying neurite outgrowth stimulated by cell adhesion molecules. Curr. Opin. Neurobiol. 4: 49-55.

Doster, S. K., Lozano, A. M., Aguayo, A. J., and Willard, M. B. (1991). Expression of the growth-associated protein GAP-43 in adult rat retinal ganglion cells following axon injury. Neuron 6: 635-647.

Fawcett, J. W., and Keynes, R. J. (1992). Peripheral nerve regeneration. Annu. Rev. Neurosci. 13: 43-60.

Felsenfeld, D. P., Hynes, M. A., Skoler, K. M., Furley, A. J., and Jessell, T. M. (1994). TAG-1 can mediate homophilic binding, but neurite outgrowth on TAG-1 requires an L1-like molecule and $\beta_{1}$ integrins. Neuron 12: 675-690.

Furley, A. J., Manalo, D., Karagogeos, D., Dodd, J., and Jessell, T. M. (1990). The axonal glycoprotein is an immunoglobulin superfamily member with neurite outgrowth-promoting activity. Cell 61: 157170.

Gaze, R. M. (1970). The Formation of Nerve Connections. Academic Press, London.

Giordano, S., Laessing, U., Ankerhold, R., Lottspeich, F., and Stuermer, C. A. O. (1997). Molecular characterization of E587 antigen: An axonal recognition molecule expressed in the goldfish central nervous system. J. Comp. Neurol. 377: 286-297.

Grafstein, B. (1986). The retina as a regenerating organ. In The Retina: A Model for Cell Biology Studies (R. Adler and D. B. Farber, Eds.), Part III, pp. 275-335. Academic Press, New York.

Grafstein, B., and McQuarrie, I. G. (1978). Role of the nerve cell body in axonal regeneration. In Neuronal Plasticity (C. W. Cotman, Ed.), pp. 155-195. Raven Press, New York.

Halfter, W., Reckhaus, W., and Kröger, S. (1987). Nondirected axonal growth on basal lamina from avian embryonic neural retina. $J$. Neurosci. 8: 3712-3722.

Kapfhammer, J., Christ, F., and Schwab, M. E. (1994). The expression of GAP-43 and synaptophysin in the developing rat retina. Dev. Brain Res. 80: 251-260.

Karagogeos, D., Morton, S. B., Casano, F., Dodd, J., and Jessell, T. M. (1991). Developmental expression of the axonal glycoprotein TAG-1: Differential regulation by central and peripheral neurons in vitro. Development 112: 51-67.

Kuhn, T. B., Stoeckli, E. T., Condrau, F. G., Rathjen, F. G., and Sonderegger, P. (1991). Neurite outgrowth on immobilized axonin-1 is mediated by heterophilic interaction with L1 (G4). J. Cell Biol. 115: $1113-1126$.

Kunz, S., Ziegler, U., Kunz, B., and Sonderegger, P. (1996). A switch in intracellular signalling after clustering of the neural cell adhesion molecules axonin-1 and NgCAM during neurite fasciculation. J. Cell Biol. [in press]

Laessing, U., Giordano, S., Stecher, B., Lottspeich, F., and Stuermer, C. A. O. (1994). Molecular characterization of fish neurolin: A growth-associated cell surface protein and member of the immunoglobulin superfamily in the fish retinotectal system with similarities to chick protein DM-GRASP/SC-1/BEN. Differentiation 56: 21-29.

Laessing, U., and Stuermer, C. A. O. (1996). Spatiotemporal pattern of retinal ganglion cell differentiation revealed by the expression of neurolin in embryonic zebrafish. J. Neurobiol. 29: 65-74.

Lemansky, P., Fatemi, S. H., Gorican, B., Meyale, S., Rossero, R., and
Tartakoff, A. M. (1990). Dynamics and longevity of the glycolipidanchored membrane protein Thy-1. J. Cell Biol. 110: 1525-1531.

Lemmon, V., Farr, K. L., and Lagenaur, C. (1989). L1-mediated axon outgrowth occurs via a homophilic binding mechanism. Neuron 2: 1597-1603.

McKerracher, L., Vidal-Sanz, M., and Aguayo, A. J. (1990). Slow transport rates of cytoskeletal proteins change during regeneration of axotomized retinal neurons in adult rats. J. Neurosci. 10: 641-648.

Mohajeri, M. H., Bartsch, U., Van der Putten, H., Sansig, G., Mucke, L., and Schachner, M. (1996). Neurite outgrowth on non-permissive substrates in vitro is enhanced by ectopic expression of the neural adhesion molecule L1 by mouse astrocytes. Eur. J. Neurosci. 8: 1085-1097.

Needham, L. K., Tennekoon, G. I., and McKhann, G. M. (1987). Selective growth of rat Schwann cells in neuron- and serum-free primary cultures. J. Neurosci. 7: 1-9.

Paschke, K. A., Lottspeich, F., and Stuermer, C. A. O. (1992). Neurolin, a cell surface glycoprotein on growing retinal axons in the goldfish visual system, is reexpressed during retinal axonal regeneration. J. Cell Biol. 117: 864-875.

Pennypacker, K., Fischer, J., and Levitt, P. (1991). Early in vitro genesis and differentiation of axons and dendrites by hippocampal neurons analyzed quantitatively with neurofilament- $\mathrm{H}$ and microtubuleassociated protein-2 antibodies. Exp. Neurol. 111: 25-34.

Pollerberg, E., Sadoul, R., Goridis, C., and Schachner, M. (1985). Selective expression of the $180 \mathrm{kD}$ component of the neural cell adhesion molecule NCAM during development. J. Cell Biol. 101: 1921-1929.

Pollerberg, G. E., and Mack, T. G. A. (1994). Cell adhesion molecule SC1/DMGRASP is expressed on growing axons of retina ganglion cells and is involved in mediating their extension on axons. Dev. Biol. 165: 670-687.

Prince, J. T., Alberti, L., Healy, P. A., Nauman, S. J., and Stallcup, W. B. (1991). Molecular cloning of NILE glycoprotein and evidence for its continued expression in mature rat CNS. J. Neurosci. Res. 30: 567-581.

Prince, J. T., Nishiyama, A., Healy, P. A., Beasley, L., and Stallcup, W. B. (1992). Expression of the F84.1 glycoprotein in the spinal cord and cranial nerves of the developing rat. Dev. Brain Res. 68: 193-201.

Rader, C., Stoeckli, E. T. U., Ziegler, U., Osterwalder, T., Kunz, B., and Sonderegger, P. (1993). Cell-cell adhesion by homophilic interaction of the neuronal recognition molecules axonin-1. Eur. J. Biochem. 215: 133-141.

Rathjen, F. G., and Schachner, M. (1984). Immunocytological and biochemical characterization of a new neuronal cell surface component (L1 antigen) which is involved in cell adhesion. EMBO J. 3: $1-10$.

Rathjen, F. G., Wolff, J. M., Frank, R., Bonhoeffer, F., and Rutishauser, U. (1987). Membrane glycoproteins involved in neurite fasciculation. J. Cell Biol. 104: 343-353.

Reh, T. A., Tetzlaff, W., Ertmaier, A., and Zwiers, H. (1993). Developmental study of the expression of B50/GAP-43 in rat retina. $J$. Neurobiol. 24: 949-958.

Ruegg, M. A., Stoeckli, E. T., Lanz, R. B., Streit, P., and Sonderegger, P. (1989). A homologue of the axonally secreted protein axonin-1 is an integral memberane protein of nerve fiber tracts involved in neurite fasciculation. J. Cell Biol. 109: 2363-2378.

Schaden, H., Stuermer, C. A. O., and Bähr, M. (1994). GAP-43 immunoreactivity and axon regeneration in retinal ganglion cells of the rat. J. Neurobiol. 25: 1570-1578.

Schwab, M. E., Kapfhammer, J., and Bandtlow, C. E. (1993). Inhibitors of neurite growth. Annu. Rev. Neurosci. 16: 565-595. 
Schwalb, J. M., Gu, M.-f., Stuermer, C. A. O., Bastmeyer, M., Hu, G.-f., Boulis, N., Irwin, N., and Benowitz, L. J. (1996). Optic nerve glia secrete a low-molecular-weight factor that stimulates retinal ganglion cells to regenerate axons in goldfish. Neuroscience 72: 901-910.

Shreyer, D., and Skene, J. H. P. (1991). Fate of GAP-43 in ascending spinal axons of DRG neurons after peripheral nerve injury: Delayed accumulation and correlation with regenerative potential. J. Neurosci. 12: 3738-3751.

Seilheimer, B., and Schachner, M. (1988). Studies of adhesion molecules mediating interactions between cells of peripheral nervous system indicate a major role for L1 in mediating sensory neuron growth on Schwann cells in culture. J. Cell Biol. 107: 341-351.

Skene, J. H. P. (1989). Axonal growth-associated proteins. Annu. Rev. Neurosci. 12: 127-156.

Skene, J. H. P. (1991). Retrograde pathways controlling expression of a major growth cone component in the adult CNS. In The Nerve Growth Cone (P. C. Letourneau, S. B. Kater, and E. R. Macagno, Eds.), pp. 463-475. Raven Press, New York.

Stallcup, W. B., and Beasley, L. L. (1985). Involvement of the nerve growth factor-inducible large external glycoprotein (NILE) in neurite fasciculation in primary cultures of rat brain. Proc. Natl. Acad. Sci. USA 82: 1276-1280.

Stallcup, W. B., Beasley, L. L., and Levine, J. M. (1985). Antibody against nerve growth factor-inducible large external (NILE) glycoprotein labels nerve fiber tracts in the developing rat nervous system. J. Neurosci. 5: 1090-1101.

Stoeckli, E. T., Kuhn, T. B., Duc, C. O., Ruegg, M. A., and Sonderegger, P. (1991). The axonally secreted protein axonin-1 is a potent substratum for neurite growth. J. Cell Biol. 112: 449-455.

Stuermer, C. A. O., Bastmeyer, M., Bähr, M., Strobel, G., and Paschke, K. (1992). Trying to understand axonal regeneration in the CNS of fish. J. Neurobiol. 23: 537-550.
Tanaka, H., Matsui, T., Agata, A., Tomura, M., Kubota, I., McFarland, K. C., Kohr, B., Lee, A., Phillips, H. S., and Shelton, D. L. (1991). Molecular cloning and expression of a novel adhesion molecule, SC1. Neuron 7: 535-545.

Vidal-Sanz, M., Bray, G. M., Villégas-Perez, M. P., Thanos, S., and Aguayo, A. J. (1987). Axonal regeneration and synapse formation in the superior colliculus by retinal ganglion cells in the adult rat. $J$. Neurosci. 7: 2894-2909.

Vielmetter, J., Lottspeich, F., and Stuermer, C. A. O. (1991). The monoclonal antibody E587 recognizes growing (new and regenerating) retinal axons in the goldfish retinotectal pathway. J. Neurosci. 11: 3581-3593.

Villegas-Pérez, M. P., Vidal-Sanz, M., Bray, G. M., and Aguayo, A. J. (1988). Influences of peripheral nerve grafts on the survival and regrowth of axotomized retinal ganglion cells in adult rats. J. Neurosci. 8: 265-280.

Villegas-Pérez, M. P., Vidal-Sanz, M., Rasminsky, M., Bray, G. M., and Aguayo, A. J. (1992). Rapid and protracted phases of retinal ganglion cell loss follow axotomy in the optic nerve of adult rats. J. Neurobiol. 24: 23-36.

Wanner, M., Lang, D. M., Bandtlow, C. E., Schwab, M. E., Bastmeyer, M., and Stuermer, C. A. O. (1995). Reevaluation of the growthpermissive substrate properties of goldfish optic nerve myelin and myelin proteins. J. Neurosci. 15: 7500-7508.

Westerfield, M. (1994). The Zebrafish Book: A Guide for the Laboratory Use of Zebrafish (Brachydanio rerio). Univ. of Oregon Press, Eugene.

Wilkinson, D. G. (1992). In Situ Hybridization: A Practical Approach. IRL Press at Oxford Univ. Press, Oxford.

Yamagata, M., Herman, J.-P., and Sanes, J. R. (1995). Lamina-specific expression of adhesion molecules in developing chick optic tectum. J. Neurosci. 15: 4556-4571. 